This work is licensed under a Creative Commons Attribution 4.0 International License.

Ovaj rad dostupan je za upotrebu pod međunarodnom licencom Creative Commons Attribution 4.0.

https://doi.org/10.31820/f.33.1.2

Diana Zalar

\title{
KONSTRUKCIJA IDENTITETA GLAVNIH LIKOVA U KNJIŽEVNIM SERIJALIMA GREGOVI DNEVNICI JEFFA KINNEYA, TIMI PROMAŠAJ STEPHANA PASTISA I SERIJALU O MIRKU MELITE RUNDEK I ILUSTRATORA MARTINA ZALARA
}

dr. sc. Diana Zalar, Sveučilište u Zagrebu, Učiteljski fakultet diana.zalar@ufzg.hr

izvorni znanstveni članak

UDK 821.09-93

821.111(73)-93.09Pastis, S.-31

821.111(73)-93.09Kinney, J.-31

821.163.42-93.09Rundek, M.-31

rukopis primljen: 19. prosinca 2020; prihvaćen za tisak: 11. veljače 2021.

Autorica razmatra konstrukcije identiteta glavnih likova u dva američka književna serijala $i$ jednome hrvatskome, koji njeguju povezanost $i$ isprepletenost ilustracije sa tekstom, a namijenjeni su suvremenome čitatelju. Polazeći od definiranja pojma identiteta kao višeslojnog, polifoničnog fenomena na osnovi razmatranja teoretičarke A. Kos Lajtman, a isto tako $i$ polifoničnih književnih struktura odabranih knjiga iz serijala Timi Promašaj, Gregovi dnevnici $i$ serijalu o Mirku, autorica obrazlaže polazišta i karakteristike tri autorska modusa izgradnje identiteta glavnih likova. Pri tome je posebno zanimaju načini kako Jeff Kinney, Stephan Pastis, te dvojac Melita Rundek i Martin Zalar poniru u psihologiju djeteta i uključuju ilustraciju u pripovijedanje. Promišljanja B. Majhuta, Š. Batinić i S. Narančić Kovač o odnosu teksta i ilustracije u knjigama za djecu, S. McClouda o stripu $i$ H. Bergsona o smiješnome bila su početna točka za taj dio rada. Polifoničnost književnoga teksta razmatra se kao supostojanje različitih diskurzivnih 
modela i strategija oblikovanja identiteta likova kao što su stilsko/značenjski sraz diskursa, prikaz necjelovite perspektive tinejdžera, pružanje više mogućnosti i razina za recepciju teksta u čitatelja različitih dobi i dr. Sva tri serijala pružaju vizualnost obilno i na mnoštvo načina. Polifoničnost, pak, likovnoga izraza u oblikovanju identiteta likova razmatra se na razinama „šifriranog” koda pripovijedanja (ironija, mašta, formalna raznolikost ilustracije, rahlost teksta), anegdotalnih izleta iz priče (vizualizacije fraza, doslikavanje, hiperbola i kontrastiranje, intertekstualnost), fenomena vizualne samosvijesti karakterističnog za karikaturalnu ilustraciju (lančana naizmjeničnost teksta $i$ slike). Humor objedinjuje poetike svih autora, a obilnost teksta i dalje drži serijale čvrsto u području žanra romana. Ipak, odnos između riječi i crteža vrlo je dinamičan $i$ živ, pa se roman bliži stripu, čak i slikovnici, iskazujući time svoje hibridne mogućnosti.

Ključne riječi: identitet; polifoničnost; procesualnost; uloga ilustracije

Dva recepcijski vrlo uspješna američka prozna serijala za djecu posljednjih su godina ažurno prevođena i u Hrvatskoj. Riječ je o Gregovim dnevnicima Jeffa Kinneya (elektronsko izdanje prve knjige objavljeno je u Americi 2004., potom dvanaest tiskanih knjiga u razdoblju od 2007. do 2020.) i serijalu Timi Promašaj Stephana Pastisa (sedam knjiga u razdoblju 2013. - 2018.). Prva knjiga potonjeg poslužila je i za filmsku adaptaciju. U Hrvatskoj su tiskane dvije knjige domaćega serijala o dječaku Mirku spisateljice Melite Rundek Mirko i glavoder (2020), Slučaj Mirkovog brata (2021), a treća je u rukopisu i pripremi za tisak (Mirko u paklu razreda). Sva tri spomenuta serijala već na prvi pogled spaja isprepletenost teksta i velikog broja ilustracija; govor pripovjedača u prvome licu, pri čemu su identiteti glavnih likova različiti književni konstrukti. Andrijana Kos Lajtman u studiji Autobiografski diskurs djetinjstva (2011) obrazlaže pojam identiteta, unikatne i neponovljive, a k tome i višeslojne (polifonične) kategorije.

Upravo iz jedinstvenih, praktički neponovljivih kombinacija nastalih preplitanjem silnica različitosti $i$ istosti, osobnog $i$ javnog, pojedinačnog i univerzalnog, unutarnjeg i vanjskog, trenutnog i dugotrajnog, oblikuje se ono što prepoznajemo kao identitet, jastvo, pojedinac. (Kos Lajtman 2011: 15)

Kos Lajtman elaborira različite teoretičare koji su se bavili pitanjima višeslojnosti osobnog i kolektivnog identiteta pa tako naglašava promišljanja Andree Zlatar koja je ustanovila da 

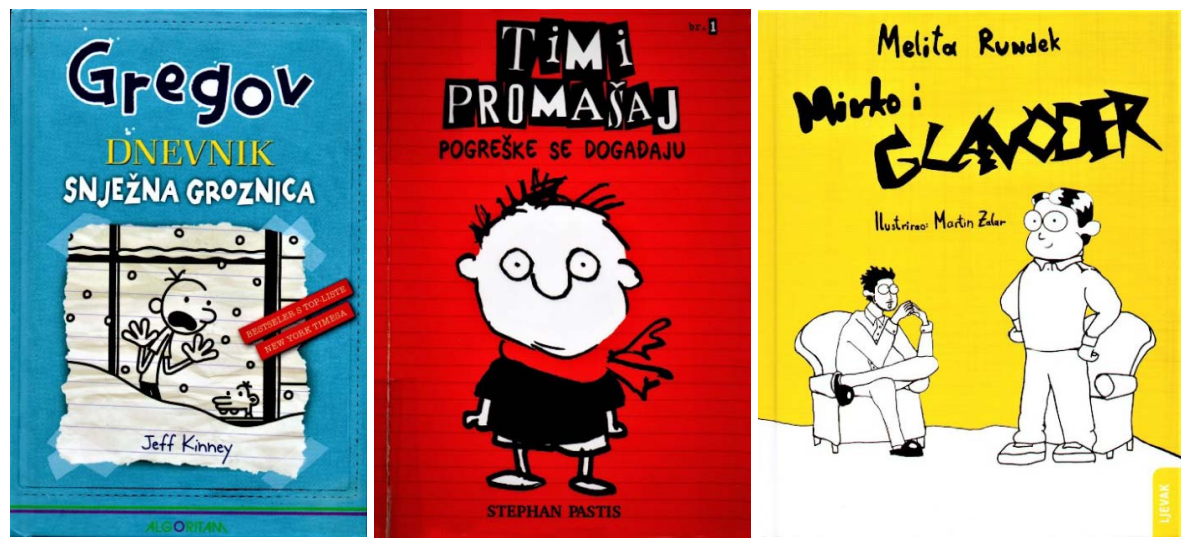

svatko istovremeno participira u različitim tipovima identiteta, od individualnih do grupnih i kolektivnih, prihvaća različite uloge u društvu, prepoznaje se ili ne prepoznaje u različitim personama. Goffmanovim riječima kazano: na sebe navlačimo društvene maske, koje mijenjamo, jedne skrivamo a druge pokazujemo, ili poput ruskih lutaka babuški, navlačimo jedne na druge. (...) (Zlatar 2004: 15, prema A. Kos Lajtman 2011: 18)

Slijedom dihotomije koja se stvara uslijed izmjenjivanja želje da se bude svoj i želje da se pripada zajednici, Kos Lajtman naglašava još jednu karakteristiku vezanu uz pojam identiteta, koju su razmatrali suvremeni teoretičari poput Jean-Luc Nancyja i Stuarta Halla, a to je procesualna karakteristika identiteta. On se razvija od rođenja do smrti, a naročito u komunikaciji s drugim osobama. Stoga ti drugi imaju odlučujuću ulogu u konstrukciji i samokonstrukciji identiteta. Pojednostavljenim riječima, kako uspostaviti različitost, ako nemamo u odnosu na što? Stoga Kos Lajtman naglašava usuglašenost suvremenih teoretičara u pitanjima višeslojnosti identiteta, koja je zapravo dvostrukoga tipa: s jedne strane je to višeslojnost identiteta jedne osobe, a s druge strane neprestano odmjeravanje, uspoređivanje i upućenost na druge osobe.

(...) glasovi, pogledi, životi, priče dodiruju, pa i prepliću sa našima - što predstavlja posljedicu 'života' drugih biografija u nama, u našoj autobiografiji, i nas u drugima. (Kos Lajtman 2011: 18) 
Tako Kos Lajtman dolazi i do polifoničnosti koja se odvija u književnome tekstu, kao supostojanje različitih diskurzivnih modela i različitih strategija oblikovanja višeslojnosti (tj. polifoničnosti) identiteta. U američkim serijalima ilustrator i pisac su iste osobe, dok u hrvatskome tekst piše Melita Rundek, a ilustrira ga Martin Zalar. Promotrit ćemo slojevitost identiteta glavnih likova (Grega, Timija i Mirka) kroz načine poniranja u psihologiju likova, te kroz karakteristike i specifičnosti ilustracija. Uz psihološke profile likova usko su vezani stilsko/značenjski sraz različitih diskurza u tekstovima (visoka maštovitost/sivilo stvarnosti, krajnja naivnost/zrelo razmišljanje i inteligentni oblici ponašanja), potom necjelovita perspektiva tinejdžera, višestruke mogućnosti razina recepcija teksta u dobno različitih čitatelja, izmjenjivanje govora u prvome licu s dijalozima i iskazima autora (skrivenog iza leđa glavnoga lika).

\section{Modusi autorskoga poniranja u identitet glavnoga lika}

\section{TIMI PROMAŠAJ}

Timi je dječak naizgled posve uronjen u svoj zamišljeni svijet detektivskoga majstora kojim se ogradio od realnosti, a odraslima je teško dostupan. U tome značenjskome kodu nastoji tumačiti sve događaje. Čitatelju se ipak daju naznake da je Timi potpuno svjestan realnosti. U poglavlju prve knjige s naslovom Tama na rubu mog kreveta za razvlačenje (Timi Promašaj, Pogreške se događaju, 2014: 178) čitamo:

Budi me pucnjava iz snajpera. Otrčim pogledati van. Mila Moskić baca mi kamenčiće na prozor.

Ili:

Majka je rekla da idemo na ručak zato da proslavimo ocjene. Ali to je bila varka. Istina je da smo išli na ručak zato da proslavimo ponovno rođenje firme Totalka Promašaj d. o. o. jer sam ja briljantno riješio sve slučajeve. (2014: 290)

Iz ovih rečenica vidi se da je Timi svjestan paralelizma svoga izmaštanoga i realnoga svijeta, ali prednost daje uvijek prvome. Međutim, o njegovu detektivskome majstorstvu drugi likovi nemaju visoko mišljenje. Distanciraju se od njega, a autor Stephan Stevens otvoreno se i nadmoćno podsmjehuje njegovome „majstorstvu” uvodeći motive vidljivih (i jasnih) tragova „zločina” 
koje Timi tumači na najpogrešniji mogući način. Primjerice, kad dječak iz razreda želi da Timi otkrije tko mu je ukrao slatkiše, Timi izjavljuje:

Kažem Tvrtku da predviđam istragu od šest tjedana. Mnoštvo svjedoka. Možda nekoliko putovanja avionom. (2014: 13)

Potom izlazi iz njegovoga stana i prolazi pored sobe brata „okradenog” dječaka. Iz lustracije je jasno da je brat kradljivac, no pri pogledu na dijete umrljano čokoladom i okruženo omotima od slatkiša, Timi zapisuje u notes samo GABI: neuredan. Timi nema mentalne poteškoće, već jednostavno ne pristaje na logiku realnoga svijeta koja ga priječi da mašta i živi bez tegoba i odgovornosti. Ovo je povezano s Timijevom realnošću u romanu: živi sa samohranom majkom koja jedva spaja kraj s krajem radeći u papirnici, pa se zbog dugova moraju preseliti iz kuće $u$ maleni stan. U narednim događajima majka izgubi posao, pa se sele njenoj teti. Oca ne poznaje, već mašta o njegovim nadnaravnim sposobnostima, a u tim je maštanjima otac međunarodni tajni agent. Sve to dosta grubo poništava autor vodeći ga u šestoj knjizi na susret s ocem koji ga je napustio dok se još nije ni rodio (Timi Promašaj, Mačak mi je ukrao hlače, 2019). Otac, vlasnik male zalogajnice, ne poklanja mu više od kratkog razgovora, iako ga na kraju romana daruje novcem za štednju kako bi jednom mogao studirati. Praznike provodi s nedovoljno poznatim osobama dok majka i njen zaručnik pokušavaju naći malo vremena za sebe. Loš je učenik. Ne može se usredotočiti na učenje ako ne vidi u tome izazov, a druženje $s$ vršnjacima ispunjeno je nerazumijevanjem. Timi kao da je dijete s problemom deficita pažnje u odnosu na neke aspekte realnoga svijeta (nastava, vanškolske aktivnosti, komunikacija s odraslima i vršnjacima). On stoga podiže maštoviti zid za obranu pred neizvjesnošću u kojoj živi i pred strahom od svijeta odraslih, te balansira u rascjepu između paralelizma izmaštane i prave stvarnosti. Pripovijedanje u prvome licu teče u prezentu. Tako nastaje privid događanja upravo sad, pred čitateljevim očima. Tako i Timi doživljava svoj život, od situacije do situacije, bez prethodnoga planiranja i uvida. Zapaža ponašanja drugih, ali ih tumači u vlastitome kodu.

Polifoničnost književne strukture realizira se na sljedeći način: unutar maštovite 'zavjese' kojom se ogradio lik-pripovjedač, autor često propusti vrlo prizemne rečenice drugih likova ili takve crteže, koji imaju učinak „provaljivanja” u Timijev svijet i pokazuju koliko je teško do njega doprijeti. Taj sraz jako dinamizira romaneskni diskurz. Primjerice, kad Timi želi „poslovno" pregovarati s majkom oko njenoga ugradbenoga ormara s odjećom, pa 
je uvjerava kako ga treba isprazniti da on i polarni medvjed mogli imati više mjesta u „detektivskome uredu”, vidimo samo njen prst koji zapovjednički pokazuje na tanjur i odgovor: Pojedi te krumpiriće! Stilskim i značenjskim srazom različitih diskurza stvara se humoristički efekt, ali i ističe majčina pozicija i širi dobna lepeza čitateljstva. Postoje likovi koji razvijaju vlastiti pristup Timiju, osim majke to su i novi učitelj i majčin zaručnik. Uz mnogo truda majka razumijeva njegov 'kodirani' govor i pruža mu toplinu. Za stolom vodi „konferencijske” razgovore s Timijem preko mobitela, uvažava njegovu potrebu za zamišljenom detektivskom agencijom - dok Timi potpuno ne prestane učiti. Onda se majka okreće metodama prisile, koje ne povećavaju Timijevu sposobnost da se usredotoči na udžbenike. Novi učitelj je u tome uspješniji. Motivira ga za rad uvjerivši ga da je otkrivanje uloge veznika i povijesnih činjenica također detektivski posao koji Timi obavlja za njega, učitelja. Ovi pristupi centripetalno se vrte oko Timija, bilo dijalozima, bilo pripovjedačevim (Timijevim) pripovijedanjem o situacijama. Timi-pripovjedač se pretvara da ne razumije metode odraslih, što čitatelja mlađe dobi ohrabruje u čitanju i osjećaju ugodne superiornosti nad likovima. Odraslome čitatelju pruža se cjelovitiji uvid u razinu dječakova odbijanja realiteta. Polifoničnosti književnoga diskurza pridonose intertekstualni nazivi poglavlja koji često korespondiraju s odraslim čitateljima jer su parafraze poslovica, naziva poznatih književnih djela i obiteljskih filmova, trivijalnih uspješnica i sapunica, te stihova poznatih pjesama (Timijev imperij uzvraća udarac, Odobravanje ludom radovanje, Daske koje život znače, Ljubav dviju žena, Kome videotelefon zvoni, Hoćeš li me još trebati, hoćeš li me još hraniti kad budem na podu?- prema stihovima poznate pjesme grupe The Beatles „When I'm sixty four”. U izvornoj inačici knjige u engleskome pod je „flour”, pa je to još vidljivije). Tu dolazimo do ugodne točke kompetencije čitatelja koju možemo usporediti sa kompetencijom čitatelja u Gregovim dnevnicima. I velike popularnosti oba serijala. Odrasli, kao i djeca, percipiraju ih zanimljivim i duhovitim.

\section{GREGOVI DNEVNICI}

Serijal je pisan kao dnevnik s navodima mjeseci i dana u tjednu, što čuva formalnu ovjeru istinitosti. Istovremeno, tajna pozicija dnevnika kao modusa izricanja biografije naizgled je "ovjera” za slobodnije i iskrenije pripovijedanje događaja i dijeljenje intime $s$ čitateljem. Dječak viših razreda osnovne škole Gregory (skraćeno Greg) u svoju je društvenu sredinu uklopljen puno bolje od Timija, no njegova je obiteljska situacija sređenija i 
ispunjena sigurnošću. Riječ je o mladiću koji ima jednako bogat unutrašnji svijet, no potpuno prožet nastojanjima da što bolje „pliva” u situacijama, bilo u školi, bilo kod kuće ili drugdje. Planira, inicira zbivanja, po potrebi zna se pretvarati, prešućivati, čak i lagati, predviđati ishode zbivanja. Zna što može reći majci, kako se ponijeti prema nastavnicima u školi, u što treba uvjeravati brata Mannyja, a što je potrebno prešutjeti prijatelju Rowleyu. Višeslojnost (polifoničnost) Gregovog identiteta u tome smislu na visokoj je razini, premda su njegova razmišljanja ponekad naivna i neupućena, čime pisac pojačava humorističnost diskurza (žao mu je što nije smio uzeti kući jare koje je dobio na lutriji, jer bi mogao svako jutro imati svježu čašu mlijeka). Ne pripada najboljim učenicima, ali nije niti na dnu te ljestvice. Poput tipičnoga tinejdžera, pokušava što lakše i s manje napora doći do cilja. U tome se skrivaju mnoge zamke, kao i prilika koju autor serijala iskorištava za životne poduke. Nerijetko se Gregovi planovi ne realiziraju onako kako ih je on zamislio u nastojanju da što lakše dođe do ciljeva, već se zbivanja počnu odvijati u nepredviđenome smjeru. U trenutku usložnjavanja situacija čitatelju postaje jasno da neće sve ići lako. Ta pozicija superiornosti naročito godi mlađim čitateljima koji se mogu smijati Gregu i na tome se velikim dijelom zasniva popularnost serijala, kao i na neprestanoj akciji.

Pripovijedanje se čvrsto drži događaja u krugu građanske obitelji i njenih znanaca i susjeda, te Gregovog školskog okruženja. Autor se nastoji ograditi od svake fantastike (sjetimo se sjevernoga medvjeda koji je Timijev „dobrovoljni pripravnik” u detektivskoj agenciji), no humor Jeffa Kinneya ipak stvara puno veći prostor za 'smještaj' vjerodostojnosti negoli što bi to bilo u realnome svijetu. Primjerice, ponukan od majke da sam zaradi za nadogradnju kompjuterske igrice, Greg se odlučuje na čišćenje snijega susjedima ispred kuća (Gregov dnevnik, Snježna groznica). Ova situacija pruža Jeffu Kinneyu mnoštvo mogućnosti za razvijanje situacija sa susjedima koje su prepoznatljive i moguće. Međutim, realnost postaje puno „rastezljivija” kad Greg biva pohvaljen u novinskim stupcima za nehotično dobročinstvo čišćenja snijega ispred pučke kuhinje. Nitko nije zamijetio njegove tajne napore, premda se sve odvijalo usred bijela dana (??) Malo je vjerojatan i dolazak hipnotizera u školu koji uvjeri učenike da su zalijepljeni super snažnim ljepilom pa tako „zalijepljeni” hodaju školom. Iako su Gregovi dnevnici fikcija već i zbog toga što nisu naslovljeni imenom autora (glavni lik nije Jeff Kinney već Greg), ovdje je riječ o maštovitosti koja odlazi u opasno visoki stupanj nerealnog, što primjerice proviruje i iz bitke oko 
skrivanja paketa WC papira u školi. Serijal je prepun ovakvih peripetija koje se nagomilavaju i svjesno ga udaljavaju od privida faktografskog.

Pogreške, slabosti i ružne strane odraslih likova temeljito se i bez zadrške ogoljuju.

U vrtiću je Cody stao u pseću kakicu za vrijeme odmora pa ga otad svi zovu Drekula. A pritom ne mislim samo na djecu. Tako ga zovu i učitelji pa čak i ravnatelj. Jedno znam sigurno. Ako ja ikada dobijem nadimak tipa Drekula, selim se u drugi grad. (Snježna groznica, 20-21)

Ovo je jedan od ključa uspjeha serijala kod široke dobne populacije, jer u njemu nitko nema status nedodirljivog. Odrasli likovi u Kinneyevoj majstorski izoštrenoj, tinejdžerskoj perspektivi najčešće su individualci koji provode nezanimljive živote prepune briga, ne nalaze istinskoga užitka ni u svojim poslovima ni u obiteljima. Robuju svojim porocima i često su nezainteresirani za druge. Ta krnja perspektiva tinejdžera vrlo je uvjerljiva jer je životna. Stoga je atmosfera serijala očekivano blago pesimistična, premda autor pazi na to da svaka knjiga ima svoj optimistični završetak.

Polifoničnost Gregova identiteta vrlo je jasna: on je istovremeno empatičan dječak spreman učiniti dobra djela, mali lažac pun smicalica, prilično egoistična jedinka najčešće zabrinuta za vlastitu udobnost, inteligentan mladić koji promiče određenu filozofiju života - koja se razvija od romana do romana. U njoj je nedvojbeno važno biti okrenut zajednici, spreman na izazove, razmišljati svojom glavom o vlastitim postupcima i postupcima drugih ljudi, imati prioritete koji su u skladu sa unutrašnjim osjećajem za pravdu i dobro. Osim toga, Greg participira u obiteljskome, a čak i u društvenome životu svoje zajednice. Iz svih događaja Greg izlazi u neku ruku promijenjen i odrasliji.

Kad je riječ o polifoničnosti književne strukture, ona je teže zamjetna. Njeni šavovi i prijelazi su puno manje vidljivi negoli u knjigama o Timiju. U Gregovim dnevnicima pripovijedanje teče neprestano u jednoj impostaciji, Gregovoj, ali su tu ilustracije koje crta J. Kinney, te one imaju posebnu ulogu o kojoj će biti riječi nešto kasnije. Pastis puno žešće ironizira svog Timija negoli Kinney Grega. U Gregovim dnevnicima ovaj postupak je skriveniji. Autor stavlja Gregu u usta naivnosti koje će ga naknadno uvesti u nepriliku. Nekad je Gregova inteligencija u neskladu s 
tom naivnošću. Primjerice, govoreći majci oduševljeno o detaljima virtualne igrice o kojoj postaje ovisan, sam sebi priprema zamku jer majka odlučuje da ga odvoji od nje.

\section{MIRKO}

Mirko, kao i Greg, živi u funkcionalnoj i cjelovitoj obitelji. U njoj dobiva potrebnu pažnju i ljubav. Pripovjedač tematizira njegov život u obitelji gdje majka upražnjava neobične hobije, otac je posvećeni kemičar, brat opsjednut ljubimcima mravima u figurativnom i doslovnome smislu, a sestra se neprestano zaljubljuje. Tematiziraju se i događaji u školi, no prva knjiga je usmjerena na profiliranje likova i početak promjena u Mirkovoj osobnosti. Do serijala o Mirku nije bilo zamjetnijega usmjeravanja pažnje na poteškoće vrlo uspješne i nadarene djece, koja imaju izvrsne ocjene, ne izazivaju probleme u školi, s lakoćom svladavaju sadržaje, a kod kuće znaju biti nezamjetna i vrlo ugodna za okolinu. Međutim, njihov školski uspjeh ponekad skriva teškoće u socijalizaciji i društvenome životu. Glavni lik ovoga serijala je previše dobar i popustljiv dječak, zbog čega ga druga djeca počinju iskorištavati i zlostavljati. U pripovijedanju o Mirku važnu ulogu ima psiholog (Mirko ga zove glavoder) s kojim dječak ostvaruje prijateljski odnos. Sva tematska žarišta Mirko počinje dijeliti u razgovorima sa "glavoderom", počinje se zauzimati za sebe i graditi svoje samopouzdanje i samopoštovanje. Psiholog mu pomaže da shvati složenu problematiku dječjih prijateljstava, odnosa u obitelji, zaljubljenosti, osjećaja dužnosti koji u životu obično dolaze isprepleteni. U početku Mirko nije oduševljen odlascima na te razgovore.

Glupo mi je što moram ići glavoderu. To je velika sramota koja će me pratiti u ovom i sljedećem i svakom idućem životu. (2020: 25)

Polifoničnost ili višeslojnost unutar glavnoga lika u početku gotovo i ne postoji. Premda ima svoje stavove, Mirko stoički podnosi izrugivanja, ne mijenja lica, ne služi se lukavštinama i nikada ne laže, pa čak ni za dobro drugoga. Sve dok ga tome, suprotno čitateljevu obzoru očekivanja, ne počne podučavati psiholog. U tome pogledu Mirko postaje lik visoko procesualnog identiteta, jer se početna minimalna polifoničnost (slaba višestrukost njegove osobnosti i slaba upućenost na interakciju s drugim likovima) povećava prema kraju prve knjige, a potom nastavlja i u sljedećima. 
U ovome serijalu možemo prepoznati četiri izrazito naglašena diskurza. To su Mirkov govor (izjednačen s pripovjedačevim), govor glavodera - psihologa (kroz njihov međusobni dijalog), govor autorice kroz usputne komentare u knjizi, te nadograđivanje i komentar priče kroz ilustracije. Evo primjera za prva tri od ova četiri diskurza:

Dakle, smijao se jako! Mislim da je i glavoder lud. Puca, jednostavno puca! Mislim da on ima puno posla, stalno s nekima čudnima i ludima razgovara, puno radi, nema slobodnog vremena, ne gleda televiziju, ne ide u kino. I pukne čovjek ko kokica! (2020: 68)

I ja zapravo mislim da on mene naručuje da ga ja škakljam i zabavljam. Jer on se u posljednje vrijeme stalno smije kad ja progovorim. Prvo sam bio oprezan i ozbiljan, a onda sam se opustio i počeo govoriti. I od tada se stalno smije.

U jednom trenu kad se nije smijao nego smješkao pa je mogao otvarati usta i govoriti, rekao mi je:

- Mislio sam da si težak, neizlječiv slučaj. Od onih predobrih i presavjesnih koje ljudi i život pregaze. Ali ima nade za tebe.

Da. Rekao je da ima nade.

- Ti jesi predobar, ali nije to tako strašno. Imaš svoje ja i svoj unutrašnji svijet.

Je, baš je tako rekao. Ne znam kada i kako je ušao u moj unutarnji svijet. Ja sam se opustio, ali vjerujem da se on školuje za to, da provaljuje u unutarnje svjetove $i$ to na stražnja vrata, hulja jedna! (2020: 96)

Poruke autorice lako se „umotaju” u Mirkove misli jer je on inteligentno i nadareno dijete, pa je lako prihvatljivo da ponekad razmišlja zrelije za svoju dob. Evo citata koji to prikazuje:

Poslije razgovora s Đulom i odmjeravanja visine, počeo sam razmišljati o visini ljudskog bića i sasvim iznenada došao do važnog otkrića! Bitnog za cijeli ljudski rod, za čovječanstvo. Došao sam do sljedećeg zaključka:

Ljudska bića nemaju stalnu i nepromjenjivu visinu. Ona se, ovisno o situaciji, mijenja. 
Pa sam još razmišljao o tom važnom poučku. Primjerice, ja. Ja sam pred pločom velik, ali jako mali kod zubara. Gledam kliješta, gledam brusilice, zna ondje ponekad i boljeti i ja se smanjim. Znam da sam ondje jako mali, sav se uvučem u sebe i izgubim važne centimetre. Najradije bih da sam nevidljiv i da nestanem, ali zubar me uvijek vidi. (2020: 51)

U serijalu o Gregu sve pršti od događanja u doslovce furioznom tempu. Ona se izmjenjuju bez predaha i usporavanja, s vrlo mnogo ilustracija. Serijal o Timiju je puno odmjereniji. Izmjenjuju se događaji, no Timijevu razmišljanju dano je puno mjesta. Zato su vizualno rečenice rahlije smještene na bjelini papira da bi ih djetetu, možda i disleksičnome, bilo lakše čitati. Ilustracija je manje negoli u Gregovim dnevnicima. Serijal o Mirku je u tome smislu bliži serijalu o Timiju. Tekst je rahlo postavljen na stranicama. Akcije i događaja još je i manje, u korist dijaloga, razmjene mišljenja, Mirkovih zaključaka. Treba reći da je knjiga Mirko i glavoder nastala u dramatičnim okolnostima u Hrvatskoj: epidemiji koja je stanovništvo stavila u specifičnu karantenu (nije bilo nastave u školama, nije se moglo putovati bez dopuštenja iz jedne županije u drugu a okupljanja su bila vrlo ograničena). Istodobno, glavni grad Zagreb pogodio je razoran potres. U tim uvjetima ilustrator i spisateljica (koji se nikada nisu vidjeli uživo) dogovarali su se oko nastajanja ilustracija i knjige, stvarao se prijelom. Stoga je okrenutost prema unutrašnjem svijetu i razgovor sa psihologom koji pokreće Mirkove promjene i akcije zapravo kompatibilna stvarnome nevoljnome vremenu koje je pogodilo sve dobne skupine u proljeće 2020. godine. Time smo se približili vrlo važnome dijelu sva tri serijala, a to su ilustracije. Ovdje bi trebalo argumentirati sljedeću hipotezu: U romanima za djecu s mnoštvom ilustracija, one postaju dio polifoničnosti identiteta likova, njegove procesualnosti, kao i polifoničnosti književnoga teksta.

\section{Ilustraciije kao neodvojivi dio polifoničnosti identiteta likova, ali i polifoničnosti tekstova}

U vremenu vizualnih komunikacija kojima su djeca izložena u suvremenom svijetu, u kojemu se i rađaju s nekom drugom strukturom percepcije nego ja koja sam knjiški moljac, tip knjige u kojem je tekst obilato popraćen ilustracijama jako je dobrodošao. On zapravo reanimira i promiče čitanje. Ilustracije su i 
vizualizacija poznatog, i odmorište i, ovisno o kvaliteti, vizualno dopisivanje teksta. Možda se nekome čini da su to knjige za nepismene. Ne, one promiču čitanje. Vole ih čitati i djeca i odrasli. Mi odrasli smo se navikli već na sve nesavršenosti i manjkavosti ovoga svijeta. On je zapravo nakrivljen i poprilično lud u raznim aspektima. Dijete se još nije naviklo na to. Ono preispituje. Nastojim pisati iz pozicije toga djeteta koje se još nije naviklo na besmislenosti svijeta. (Melita Rundek, iz korespondencije s autoricom članka)

Prema Henry Bergsonu u studiji Smiješno (1987), u književnim djelima postoji humor koji proizlazi iz onoga što se jezikom izražava (kao značenjski dio), i onaj humor koji jezik stvara (kao oblik). Međutim, ilustracije u romanima o Gregu, Timiju i Mirku uvelike usložnjavaju stvar, jer one također i izražavaju značenja (crteži, „oblačići” teksta, natpisi itd.), ali i stvaraju značenja (formom i oblikom ilustracije, odabranom vrstom vizualne prezentacije). Kad je riječ o odnosu ilustracije i teksta u ovim djelima, promotrimo promišljanja Berislava Majhuta i Štefke Batinić (2017). U poglavlju Teorijska polazišta povijesti slikovnice bave se određenjem uloge ilustracije u ilustriranoj knjizi i slikovnici, pri čemu polaze od pitanja:

Razlikuje li se figurativni crtež ili, bolje, takav likovni material (crtež, slika, kolaž, fotografija i sl.) od ilustracije? Ili je to jedno i jednako? (2017: 25)

Uz pretpostavku da postoji živi suodnos ilustracije i teksta u ilustriranoj knjizi dolaze do zaključka kako se pravo značenje crteža u ulozi ilustracije otkriva u suodnosu sa tekstom. Isto tako, ilustracija može popuniti mjesta u tekstu u kojima se izostavljaju neki detalji i događaji.

Ilustracija i tekst ulaze u bogate suodnose u kojima svaka strana dobiva nešto od onog drugog. (2017: 27)

Pri tome, ako su tekst i ilustracija u ilustriranoj knjizi u suprotnosti, jasna je hijerarhija i tekst je za čitatelja onaj koji je relevantan. Kad je riječ o romanima koje ovdje razmatramo, ima više primjera kad ilustracija (crtež) zapravo ne samo da nadopunjava tekst, već oponira tekstu, ironizira ga, daje humoristički komentar. Ove su karakteristike, prema tome, bliže karakteristikama slikovnice negoli ilustrirane knjige. Zamagljuje se i kriterij prema kojemu se ilustrirana knjiga razlikuje od slikovnice po tome što $u$ 
slikovnici preteže slika, a u ilustriranoj knjizi tekst. To jest, u slikovnici je taj odnos ravnopravan, harmoničan. Potonje se može zapaziti u većoj ili manjoj mjeri u sva tri serijala. Odnosi se, s obzirom na „klasični” roman za djecu, mijenjaju u korist slike, iako tekst još uvijek preteže. Ilustracije više ne pripadaju samo spacijalnom izražavanju neovisno o vremenskome slijedu priče, već je i te kako važno kojim redoslijedom iz gledamo dok čitamo serijal. Ilustracije čak ponekad remete slijed priče i počinju pričati još nešto drugo. To ne ide tako daleko da bi tekst imao drugi smisao kad se čita s ilustracijama, ali ima bogatiji smisao na više razina (jedna od njih je intertekstualnost). Ilustracije u romanima o Gregu, Mirku i Timiju nisu samo korektno popunjena mjesta neodređenosti u tekstu, već prekoračuju okvire zadane tekstom.

Tu se otvara pomalo „pustolovni” procjep u kojemu autori koketiraju sa slikovnicom. K tome ide u prilog da bi bilo teško zamisliti da Gregove dnevnike, ili romane o Timiju ili Mirku ponovno ilustrira netko drugi, s obzirom da je u prva dva slučaja riječ o istoj osobi i cjelovitom autorstvu, a u trećemu o kreativnom procesu zajedničkog stvaranja vizualnog predstavljanja likova između spisateljice i ilustratora.

\section{MIRKO}

Primjeri funkcije ilustracija u prikazu polifoničnosti i procesualnosti identiteta Mirka u knjigama Mirko i glavoder i Slučaj Mirkovog brata:

- vizualizacija fraza i zaključaka (Ilustrator Mirka prikazuje onako kako se on osjeća.)

Ja sam crna ovca. Ja sam bijela vrana.
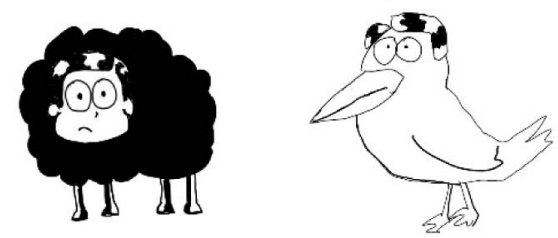
(Kad Mirko počinje stjecati samopouzdanje i čini nešto lijepo za sestru):

Ljudska bića nemaju stalnu i nepromjenjivu visinu. Ona se, ovisno o situaciji, mijenja.
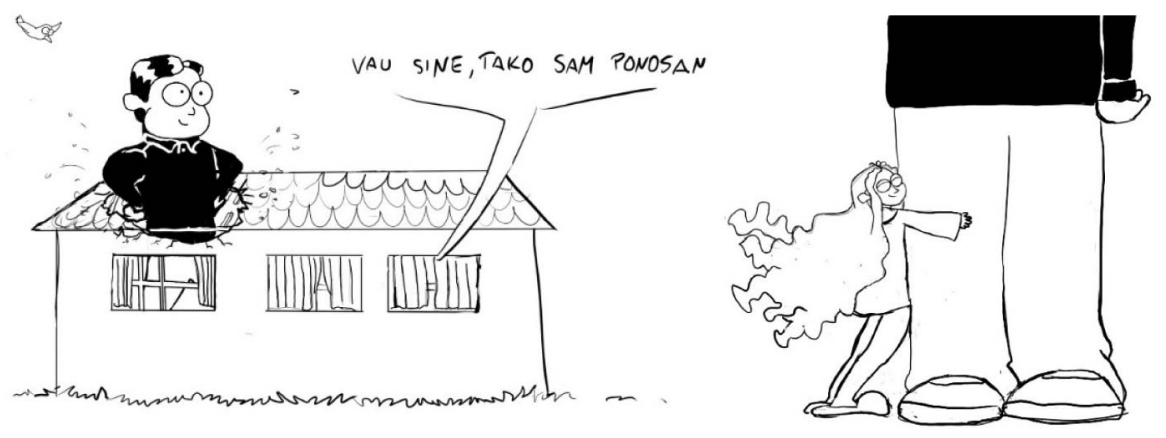

- samostalno asociranje ilustratora koje humoristički interpretira Mirkov napredak - „doslikavanje” teksta (Mirko prikazan kao King Kong, kad osnažen više nema potrebu dolaziti psihologu na razgovore)

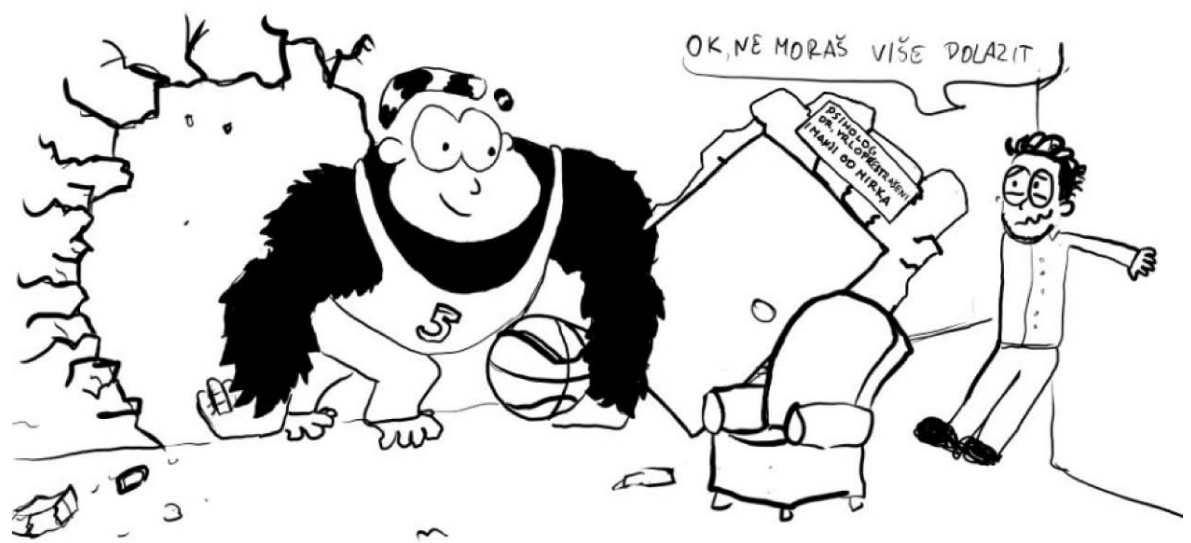


- ilustracija kao odmorište u tekstu, ali govori i o osobnom identitetu životinjskoga lika

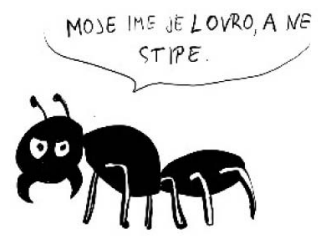

- hiperbola i kontrastiranje (prikaz Mirkovog društvenog identiteta kroz njegov stav o ljubavi)

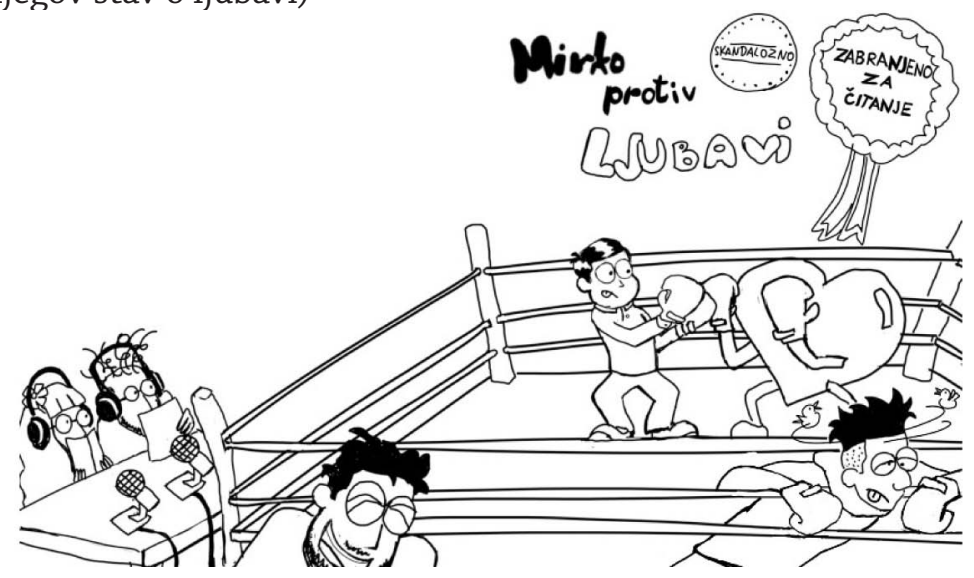

- ilustratorovo nadograđivanje teksta (Mirko u tekstu obrazlaže kako na cijelome svijetu nema djevojke za njega, ali ilustrator crtežima i komentarima likova astronautkinje i bića s druge planete koji ne postoje u tekstu izražava kako je Mirko vrijedan ljubavi)

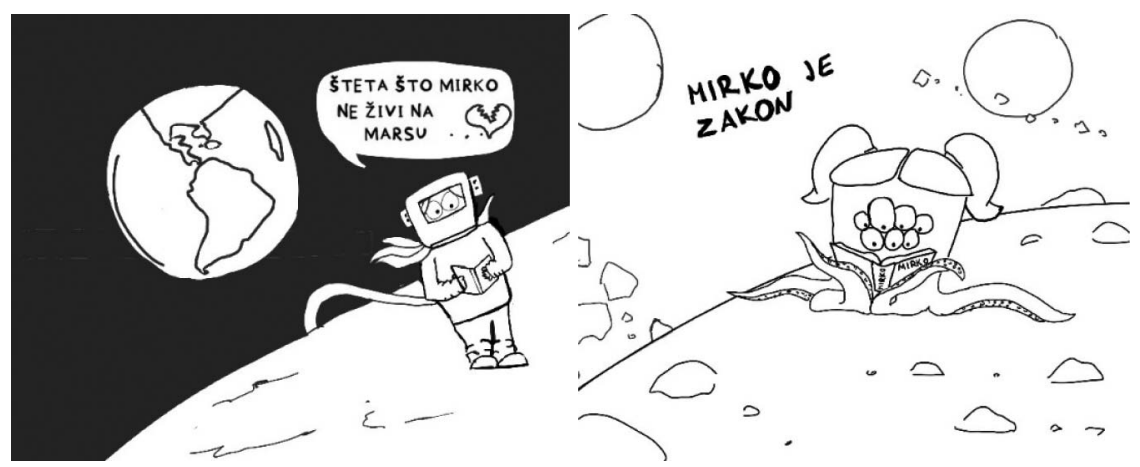


- ilustrativno potkrjepljivanje značenjski prenaglašenih izjava spisateljice

Kad se komentira kako profesori ne dopuštaju čitati ovu knjigu, vidimo sljedeću ilustraciju:

Pitamo se zašto je ne dopuštaju čitati?

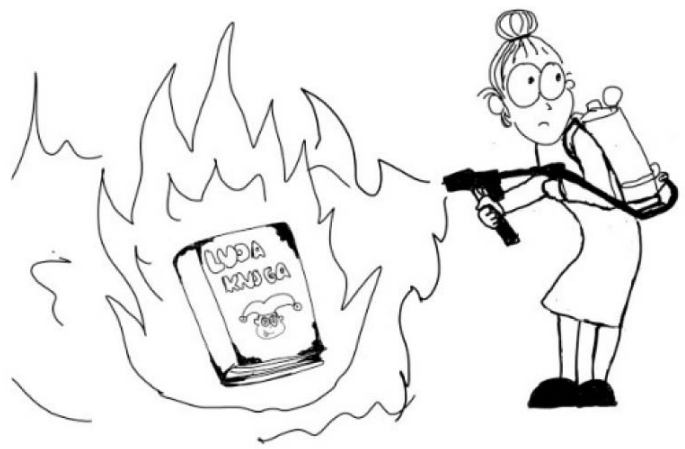

Zbog toga što je u njoj glavni lik koji je previše dobar, ili je neki drugi razlog u pitanju? Ne daje se eksplicitni odgovor, ali izraz odrasle osobe (profesorice) daje naslutiti da ona čini nešto što ne bi smjela.

- ironiziranje ilustracijom, primjerice Mirkove pretjerane sklonosti prema francuskoj salati

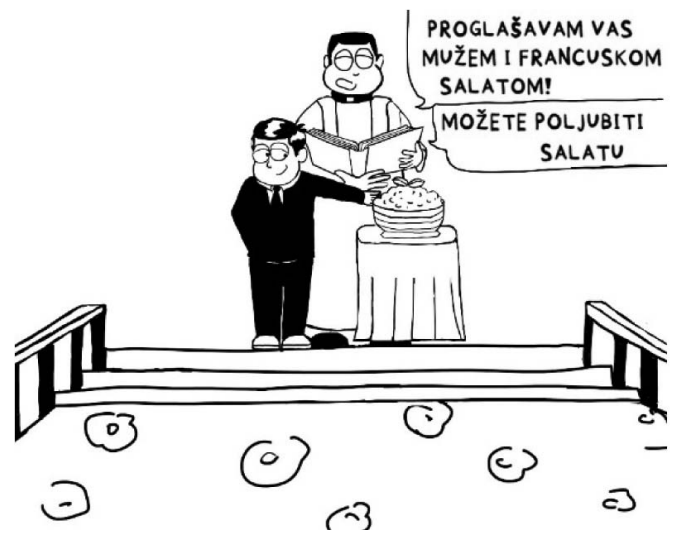

Između teksta i ilustracija razvija se zanimljivi „dijalog”, u kojemu ilustrator prema potrebi, sklonostima i dogovoru sa spisateljicom prati tekst, razvija neka nova njegova značenja, naglašava njegovu humorističnost. 
Time zapravo ne samo da potiče djecu na čitanje, već naglašava i vizualno pojašnjava dubinske slojeve teksta koji možda djetetu nisu u prvome čitanju posve pred očima. Ovako to postaju, i doslovce i figurativno. Treba naglasiti da intertekstualnost koju donose ilustracije nije isključiva - ako djeca ne znaju za filmove o King Kongu, ili nisu upoznata sa uvriježenim značenjima sintagmi „bijela vrana” i „crna ovca”, i bez tih znanja bit će im jasna poruka i povezanost ilustracije sa tekstom. Tako su ilustracije dvojno pozicionirane: govore više ili manje, ali uvijek pogađaju put do adresata. Likovi su najčešće blagih i vedrih lica. Ilustrator i spisateljica pozivaju čitatelja na dijalog. Pozicija poistovjećivanja pripovjedač-Mirko izmjenjuje se s pozicijom ilustrator-Mirko, dajući na znanje koliko je Mirkov svijet bogat i sadržajan, a tekst istovremeno poticajan za različita maštanja, nadograđivanja i ideje. Tako se i crtežima i tekstom iskazuju mijene i procesualnost Mirkova identiteta. Zanimljivo je promatrati razvoj ovoga koncepta između spisateljice i ilustratora. S napretkom priče ilustrator se sve više odvažuje upisivati u ilustracije svoje komentare (u drugom romanu vidljiva je još veća sloboda u tome, a i ilustracija je gotovo dvostuko više). Ti slikovni komentari odvode ilustratora u male digresije povezane s pričom kojima se čitatelj može po volji prepustiti, razvijati ih u mašti i nadograđivati. Ili se može jednostavno vratiti temeljnoj priči i dalje je slijediti. Iako bi se priča mogla slijediti nesmetano i bez ilustracija, one daju mogućnosti za tješnje poistovjećivanje i poosobljavanje s pričom i glavnim likom. Čitateljeva pažnja s njima se produbljuje.

\section{TIMI PROMAŠAJ}

Timi-pripovjedač ispovijeda se čitatelju kako je jednom u tekstu morao napisati Magellanovo ime kao odgovor na pitanje o svjetskim istraživačima. Napisao ga je ovako:

\section{Chang}

Odgovorio sam Chang jer je pitanje glasilo: „Tko je prvi oplovio svijet?" A ja nisam znao. Ali znao sam da je Chang najčešće prezime na svijetu. Pa sam riskirao. (Timi Promašaj, Pogreške se događaju, 2014: 19)

U ovome primjeru je vidljivo kako knjiga prevedena iz posve različite i vrlo udaljene sredine gubi svoja značenja u odnosu na dijete čitatelja koje nije pripadnik te sredine. Teško da će hrvatsko dijete razumjeti kako je 
prezime Chang najčešće prezime na svijetu zbog najmnogoljudnije nacije na svijetu, a to je kineska. Hrvatska, u odnosu prema Americi, Italiji i mnogim zemljama Zapadnoga svijeta, ima zanemariv broj građana Kineza. Ovu će aluziju shvatiti odrasli koji čitaju knjigu. No, odmah dalje slijedi ilustracija školskoga listića. Na pitanje „Tko je napisao Ustav Sjedinjenih Država?” koči se odgovor

\section{Chang}

koji izaziva smijeh i kod mlađih čitatelja koji ne znaju podatak o nadmoćnome broju Kineza u odnosu na druge nacije.

Ne treba posebnoga komentara za ovakav crtež učitelja, premda humoristički učinak ima tek prikaz kako ga vidi Timi u svojoj mašti:
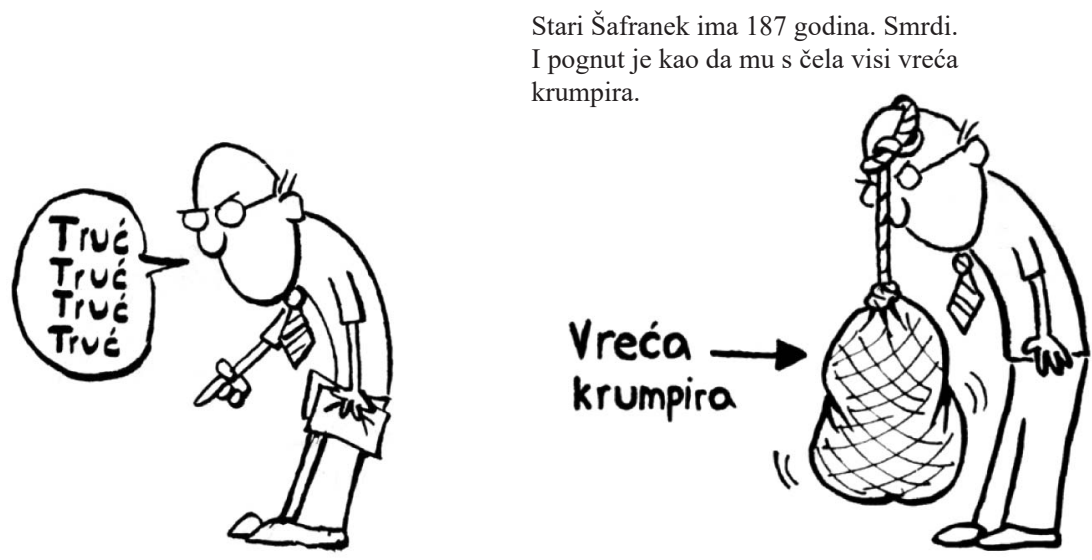

To je stari Šafranek. On mi je učitelj.

U serijalu Timi Promašaj tekst je potkrijepljen mnoštvom krajnje jednostavnih crteža. Značenjski, u njima se ponavlja, nadograđuje (kao u predstavljenim primjerima) ili izražava suprotnost prema rečenome, a Timi i drugi likovi najčešće su pozicionirani u apelativnoj, tzv. anfas perspektivi. Evo kako Timi dočekuje majčinoga prijatelja: 
Tada sam primijetio da mu nešto raste na bradi.

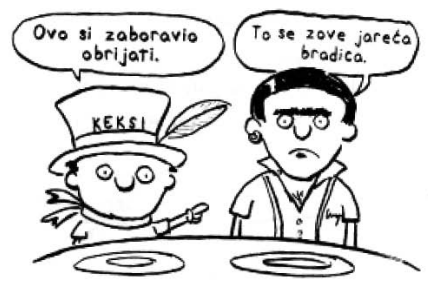

Onda sam primijetio da ima samo jednu naušnicu.

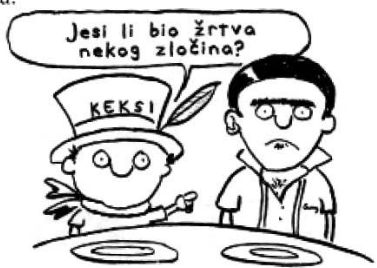

Uznemiren našim razgovorom, povukao sam se u kupaonicu da u detektivski dnevnik upisem njegovu preciznu procjenu.

162

Gledajući čovjeka koji izgleda nasilno kao da voli šakom obarati ljude, a čita sabrana djela Emily Dickinson, Timi analogijom zaključuje da je i ta spisateljica vjerojatno poznata "gnječiteljica šakom”. No ipak mu je u tome smislu pomalo čudan njezin portret.

Ako ona može gnječiti stvari šakom, onda je njezina fotografija malo čudna.

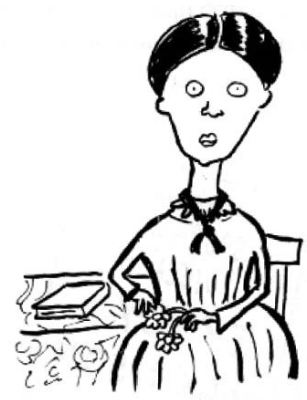

EMILY DIGKINSON Gnjeciteljica Strari 
Likovi na crtežima, jednakih očiju koje se svode na kružiće s točkom u sredini, bez osmjeha (namršteni, rezignirani, začuđeni) djeluju kao da neprestano zazivaju pomoć. Istovremeno, tekst nas nasmijava. Poput samouvjerenoga komičara koji „izbacuje” viceve a sam se nikada ne nasmije (asocijaciju na Bustera Keatona teško je izbjeći), pratimo Timijeve nevolje. Zaključak bi mogao biti da izražavaju Timijevo duhovno stanje, njegovu zatvorenost prema drugim identitetima, tjeskobu. Likovi na crtežima postaju karikaturalno ogoljena stanja, kao da usputno lebde na stranicama i pojačavaju Timijev doživljaj uznemirujuće i tjeskobne stvarnosti. Riječ je o krajnje pojednostavljenim crtežima koje kao da je donio neki vjetar koji je prohujao tiskarom. Lebde u prostoru stranica u obliku skica, crteža, pisama, popisa, sastavaka, prikaza dijela dokumenata, notnih zapisa, uvećanih detalja, stranica istrgnutih iz notesa katkad postavljenih naopačke, prikaza jednostavnih plakata s natpisima. Stoga je formalna raznolikost ilustracija $u$ serijalu veća nego u druga dva serijala.

\section{Formalna raznolikost ilustracije kao u stripu}
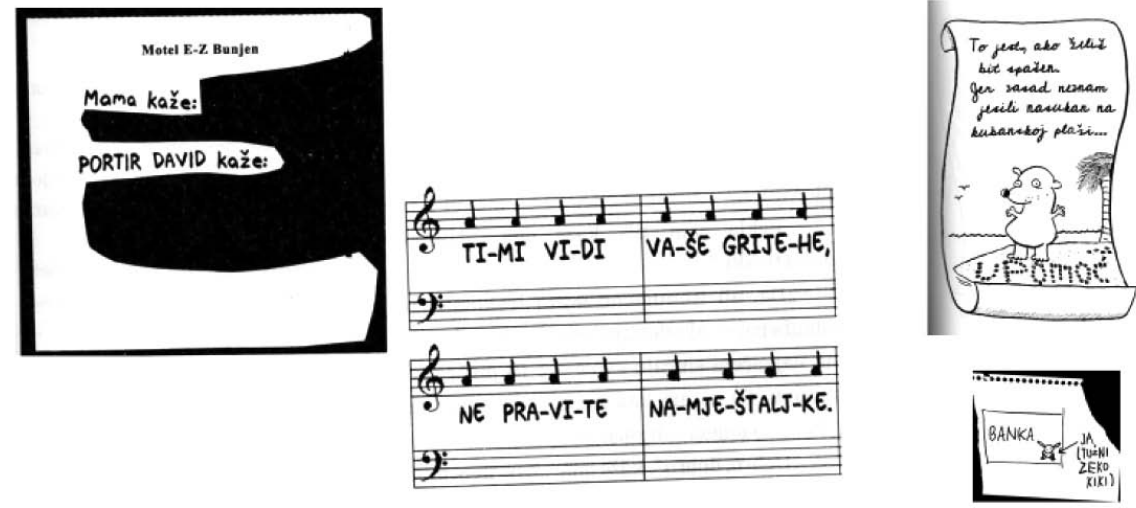

Istodobno, sugerira se da je detaljan crtež nepotreban jer je važnija atmosfera koju on izražava. Lebdećom impostacijom brzopoteznih, naizgled usputnih ilustracija pisac postiže opći dojam neizvjesnosti, straha pred svijetom koji više pripada odraslima i u kojemu je Timi osuđen da bude statist, za razliku od svijeta koji u njemu živi iznutra. No, ipak je crteža razmjerno velik broj, čime proizlazi da oni imaju još jednu važnu ulogu - razdvajanja redaka teksta. Čine ga vrlo rahlim, što privlači djecu i odrasle koji inače odustaju od čitanja čim uoče gusto pisani tekst. Serijal Timi 
Promašaj zapravo je složeni primjer književno-likovne strukture. Budući da svjesno cilja na široku lepezu dobnih skupina, djeca se u neke razine ne mogu uživjeti a to se od njih i ne očekuje. Ovo je prednost u stjecanju popularnosti serijala.

\section{GREGOVI DNEVNICI}

Što je s ilustracijama u Gregovim dnevnicima? One su toliko bitan dio teksta da se on bez njih i ne može često razumjeti do kraja. To se može postići samo ako piše i crta ista osoba, kao što je ovdje i slučaj. Kao da Jeff Kinney spontano prelazi iz jednoga medija na drugi, s pisanja na crtanje i obrnuto, pričajući priču. Ono što nije izgovoreno ili rečeno u tekstu, izgovara se ili prikazuje ilustracijom.

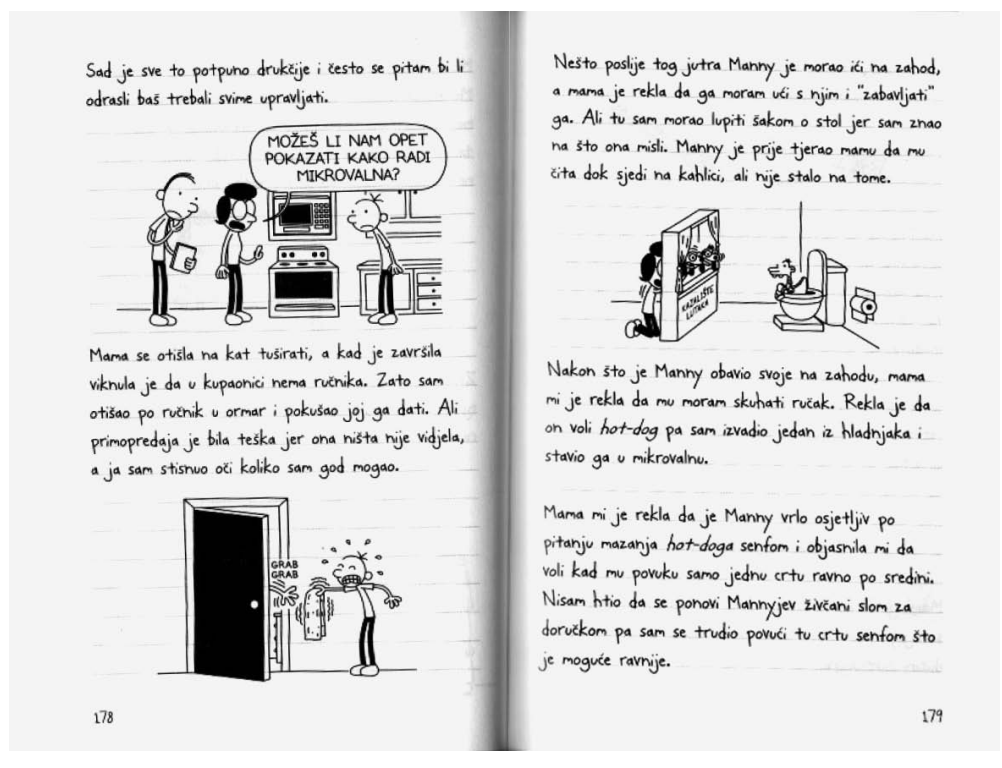

Primjerice, Greg ne želi zabavljati mlađega brata u zahodu, a zašto, vidimo SAMO na ilustraciji - majka mora izvesti čitavu kazališnu predstavu dok Manny „učini svoje”.

Ovakav način izlaganja najsličniji je stripu. Stoga je crtež i najzastupljeniji u odnosu na sva tri serijala. Crteži su smješteni po principu „nekoliko redova teksta, potom crtež”. Iznimka je kad umjesto crteža dođe plakat, ili se zbivanja komentiraju u listu Kvartovsko ogovaralo. Ljudi su pri- 
kazani karikaturalno, kao što je to čest slučaj u stripu. Kroz fenomen koji je Scott McCloud u studiji Kako čitati strip - nevidljivu umjetnost (2005., eng. 1993. Understanding Comics - The Invisible Art) nazvao fenomenom nevizualne samosvijesti, mogao bi se promatrati svaki od razmatranih serijala. No, to bi bila tema za poseban rad. Napomenimo ovdje da se Kinneyevi crteži stupnjevito razlikuju od „stvarnosnog” izgleda. Što je manje naznaka u prikazu likova, to se više čitatelja može s njima poistovjetiti jer ih karikaturalnost ljudskih likova poziva da detalje nadograđuju i nesvjesno sami. McCloud naglašava kako sve što ljudi doživljavaju pripada ili u područje osjeta ili se može grupirati u područje koncepata, a ljudski identiteti za njega trajno pripadaju konceptualnome svijetu. U tome smislu karikaturalnost likova prikazuje zapravo njihov unutarnji svijet, njihove identitete koje čitatelj nadograđuje u skladu sa svojim iskustvom. Veća realističnost pozadina potiče čitatelja da se „premjesti” u lik i tako uđe u priču. Lica djece koje Jeff Kinney crta su starmala, nosevi često veliki a brade uvučene. Ironizira se razlika dijete-odrasli. Time je složenost identiteta djeteta stavljena na istu razinu sa složenošću identiteta odrasloga čovjeka. Gregova majka podsjeća na muhu jer joj se kratkovidne oči ne vide iza naočala, čime se možda sugerira da često dosađuje. Međutim, čitateljevo nesvjesno nadograđivanje u velikoj je mjeri upravljano tekstom koji se isprepliće $\mathrm{s}$ ilustracijama. Riječ je ipak o romanu, a ne o stripu. Ova mogućnost identifikacije čitatelja s karikaturalnošću ilustracija posebna je karakteristika knjiga o Gregu. Stephan Pastis ilustracijama puno više daje emocionalni ton serijalu, dok Martin Zalar rado odlazi u vlastite humorističke digresije kako bi čitatelj u mislima nadograđivao anegdotalnost prizora.

Bogatije nacrtanom pozadinom likova na crtežima, interijerima i eksterijerima, zbivanja se čvršće „ukopavaju” u zadanu realnost priče. Okolina prikazanim licima daje ponekad drugi ton i značenje. Mnoštvom ilustracija položenih u blokove teksta jednakog ili sličnog oblika Jeff Kinney i formalno ilustraciju postavlja na razinu jednaku pripovijedanju tekstom, što bi se moglo nazvati lančanim nadograđivanjem.

Smiljana Narančić Kovač (2015) u poglavlju Razlikovanje slikovnice $i$ stripa - granični slučajevi navodi definiciju Davida Carriera za kojega je strip

miješani umjetnički oblik koji je dijelom riječ i dijelom slika (2015: 196)

$i$ ističe kako su stapanja jezičnih i slikovnih aspekata u stripu usmjerena prema jedinstvenosti diskursa toga žanra. Može se zamijetiti da u romanima o 
Gregu postoji upravo zavisan odnos između stripovskih elemenata i teksta romana jer jedan drugoga izmjenjuju i nije ih moguće odvajati. Ova činjenica baca novo svjetlo na dječji roman kao žanr. U rijetkim slučajevima postoji zalihosnost između teksta i onoga što se izgovara na ilustraciji, pa se i time može argumentirati pomak prema stripovskoj „organizaciji” romana.
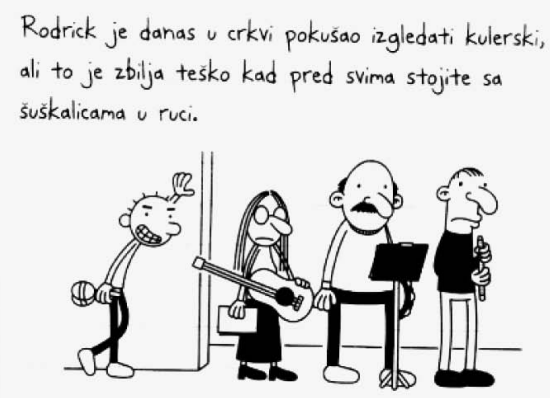

Ali totalno zham kako je to kad vas navedu da se prijavite za nešto, a ne kažu vam sve o tome. Lahi me mama nagovorila da se prijavim u crkveni predpubertetski klub, a onda sam stivatio da nisu bas strogo odredili tko bi sve trebao spadati u tu kategoriju "predpubertetski".

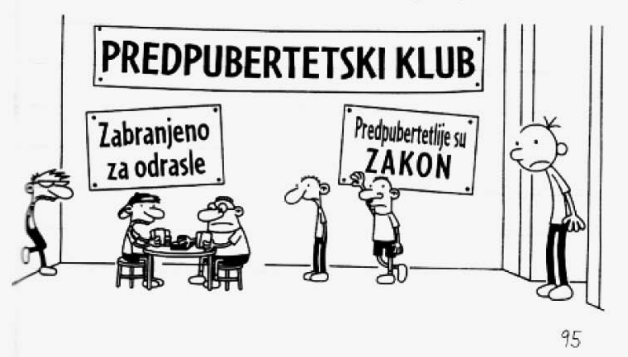

\section{Zaključak}

Identiteti likova Grega, Timija i Mirka razvijaju se u odnosu na druge identitete (likove) u serijalima. Istodobno, jasna je heterogena unutrašnjost glavnih likova (osobni identiteti u igri odnosa pripadnosti-nepripadnosti užem obiteljskom krugu i društvenoj sredini). Nadalje, dvojna procesualnost identiteta - prema unutra i prema van - iznesena je u tri posve različite autorske poetike. U njima važnu ulogu imaju jednako tekstualna 
poniranja u identitete likova, kao i brojne ilustracije. Identitete tri posve različita dječaka autori su čitateljima približili ne samo govorom u prvome licu, već i polifoničnošću književnoga tkiva, jednako teksta ako i ilustracija. Primjerice, na razini teksta, Pastis se služi ironijom i „kratkim rezovima” koji kontrastiraju Timijeve iskaze sa iskazima drugih likova koji ne participiraju u Timijevom zamišljenom svijetu. Time zorno predočava barijeru koju Timi podiže oko sebe kako bi se zaštitio. Rundek kontrapunktira Mirkove, psihologove i vlastite opservacije tako da su ove potonje stilizirane za Mirkova „usta”, prikazujući natprosječno nadarenog i inteligentnog dječaka. Kinney u teško vidljivim „šavovima” spaja fakciju, fikciju i tinejdžersku naivnost, što često priprema teren za nepredviđene fabularne zaplete. I odnos autora prema suvremenosti vrlo je angažiran. Pripovjedač pušta da likovi dječaka manje ili više otvoreno govore o sebi, obitelji i društvu. Ilustracijama se, pak, također postiže stupnjevanje u gradnji identiteta glavnih likova, pri čemu je fenomen vizualne samosvijesti (karakterističan za karikaturalnu ilustraciju) usmjeren: bilo na emocionalni habitus likova i „šifrirani” kod pripovijedanja koji podižu razinu empatije prema liku (Pastis); bilo na mogućnosti anegdotalnih izleta iz priče koji su s njome povezani, ali istovremeno potiču čitatelja na vlastitu imaginaciju i nadograđivanje u skladu s iskustvima (Zalar); bilo na što detaljniji prikaz okruženja likova kako bi čitatelj što lakše u njega „ušao” i počeo ga i nesvjesno nadograđivati (Kinney). Svemu tome treba pridodati da obilnost teksta i dalje drži serijale čvrsto u području žanra romana, a ilustracije su manje ili više u njegovoj „vlasti”. Ipak, taj odnos je vrlo dinamičan i živ, što utječe na popularnost romana i njihove crossover pozicije, ali i na razumijevanje pojma romana kao žanra. Svijest autora da suvremeno dijete (ali i odrasli) treba sve veću vizualnu nadogradnju i komentar teksta, jasna je. Stoga vizualnost pružaju obilno i na mnoštvo načina. Funkcijama, formalnim obilježjima i kompetencijama ilustracija roman se bliži stripu, pa čak i slikovnici. To je posebno vidljivo u segmentima djela gdje tekst ne bi bio razumljiv bez ilustracije, ili tamo gdje ilustracija obilno komentira tekst i kreativno ga „nadopisuje, tj. nadoslikava”. I tekstovi i ilustracije, $\mathrm{k}$ tome, obiluju intertekstualnošću. U tri romaneskna serijala o kojima je riječ, žanr iskazuje svoje hibridne mogućnosti inventivnom igrom na planu riječi i crteža. 


\section{Literatura}

\section{Izvori}

Kinney, Jeff (2017) Gregov dnevnik, Snježna groznica, Algoritam, Zagreb.

Kinney, Jeff (2017) Gregov dnevnik, Lijevo smetalo, Algoritam, Zagreb.

Pastis, Stephan (2014) Timi Promašaj, Pogreške se događaju, Profil, Zagreb.

Pastis, Stephan (2015) Timi Promašaj, Pogledajte što ste učinili, Profil, Zagreb.

Rundek, Melita; Zalar, Martin (2020) Mirko i glavoder, Ljevak, Zagreb.

Rundek, Melita; Zalar, Martin (2021) Slučaj Mirkovog brata, Ljevak, Zagreb.

\section{Stručna literatura}

Bergson, Henri (1987) Smijeh, O značenju komičnoga, Znanje, Zagreb.

Hranjec, Stjepan (1998) Hrvatski dječji roman, Znanje, Zagreb.

Kos-Lajtman, Andrijana (2011) Autobiografski diskurs djetinjstva, Naklada Ljevak, Zagreb.

Majhut, Berislav; Batinić, Štefka (2017) Ilustrirani pripovjedni tekst i slikovnica, U: Hrvatska slikovnica do 1945., Hrvatsku školski muzej, Učiteljski fakultet, Zagreb.

McCloud, Scott (2005) Kako čitati strip - nevidljivu umjetnost, Mentor, Zagreb.

Narančić Kovač, Smiljana (2015) Jedna priča - dva pripovjedača, ArTresor, Zagreb.

Pamungkas, Catur Sapto, „Character in children realism of Jeff Kinney's Diary of Wimpy Kid: The Ugly Truth”, http://journal.student.uny.ac. id/ojs/index.php/quill/article/viewFile/14461/14038, posjet 19. prosinca 2020.

Transcript from a video intervju with Stephan Pastis, https://www.readingrockets.org/books/interviews/pastis/transcript, posjet 19. prosinca 2020.

Zima, Dubravka (2011) Kraći ljudi, Povijest dječjeg lika u hrvatskom dječjem romanu, Školska knjiga, Zagreb. 


\section{SUMMARY}

Diana Zalar

THE CONSTRUCTION OF THE IDENTITIES OF THE MAIN CHARACTERS IN THE LITERARY SERIES DIARY OF A WIMPY KID BY JEFF KINNEY, TIMMY FAILURE BY STEPHAN PASTIS AND THE SERIES ABOUT MIRKO BY MELITA RUNDEK AND THE ILLUSTRATOR MARTIN ZALAR

The author discusses the constructions of the identities of the main characters in two American and one Croatian literary series, which nurture the connection and intertwining of illustration with text, and are intended for the modern reader. Starting from the definition of the concept of identity as a multi-layered, polyphonic phenomenon based on the consideration of literary theorist A. Kos Lajtman, as well as polyphonic literary structures of the three selected books from the series Timmy Failure, Diary of a Wimpy Kid and a series about Mirko, the author explains the starting points and characteristics of the three authorial modes of building the identity of the main characters. In doing so, she is particularly interested in the ways in which Jeff Kinney, Stephan Pastis, and the duo Melita Rundek and Martin Zalar delve into child

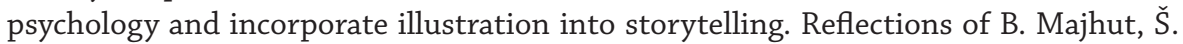
Batinić and S. Narančić Kovač on the relationship between text and illustration in children's books, S. McCloud on comics and H. Bergson on the humor in literature were the starting point for this part. The polyphony of a literary text is considered as the coexistence of different discursive models and strategies of shaping the identity of characters such as stylistic / semantic clash of discourse, presentation of incomplete perspective of teenagers, providing more possibilities and levels for text reception in readers of different ages, etc. All three series provide the visual side of novels in a multitude of ways. The polyphony of illustrations in shaping the identity of characters is considered at the levels of "encrypted" narrative code (irony, imagination, formal diversity of illustration, fragility of text), anecdotal excursions from the story (visualization of phrases, hyperbole and contrast, intertextuality), a phenomenon of visual self-awareness characteristic of caricature illustration (chain alternation of text and image). Humor unites the poetics of all authors, and the abundance of text still holds the series firmly in the field of the novel genre. Still, the relationship between words and drawings is very dynamic and lively, so the novel gets closer to comics, even picture books, thus expressing its hybrid possibilities.

Key words: identity; polyphony; processuality; the role of illustration 